\title{
IMPLEMENTASI SISTEM ABSENSI DAN PENGGAJIAN PADA PT. OPHTHALINDO JAYA MENGGUNAKAN METODE ZACHMAN
}

\author{
${ }^{1}$ Muhammad Rozis Al Yasah, ${ }^{2}$ Sugiyono* \\ Program Studi Teknik Informatika, STIKOM ( Cipta Karya Informatika) \\ Jl.Radin Inten II No.8A, Duren Sawit, Jakarta Timur, Indonesia \\ Rozisalyasah12@gmail.com, inosoguy007@gmail.com
}

Received: 2021-08-24, Revised: 2021-08-30, Accepted: 2021-09-02

\begin{abstract}
Abstrak
PT. Ophthalindo Jaya, Keluhan ataupun masukan dari beberapa karyawan sangat direkomendasikan untuk meminimalisir terjadinya kelalaian dalam membuat surat secara manual baik itu secara internal maupun external, Keluhan ini yang membuat untuk mencari solusi agar pengaturanya menjadi lebih dinamis dalam pengoprasian suatu perusahaan yang bergerak dibidang alat kesehatan, Metode yang akan di lakukan adalah membuat suatu cara agar semua dapat memudahkan karyawan untuk lebih aktif dalam kehadiran maupun kordinasi dengan masing masing departemen, Suatu system yang melakukan absensi untuk mempermudah karyawan mengakses dari luar, penulis juga akan menggunakan CODEIGNITER untuk memudahkan pengguna melalui perangkat mobile, Sehingga cara ini dapat meminimalisir terjadinya kesalahan dalam melakukan proses absensi dan penggajian.
\end{abstract}

Kata Kunci : Absensi, Data monitoring, Penggajian, Slip Gaji, Perizinan

Abstract

PT. Ophthalindo Jaya, Complaints or input from certain things to avoid negligence both internally and externally, This complaint makes to find a solution so that the arrangement is more dynamic in the operation of a company engaged in medical devices, The method that will be carried out is to make a way so that all can make it easier for employees to be more active in attendance and coordination with each department, A system that does attendance to make it easier for employees to access from outside, the author will also use CODEIGNITER to make it easier for users via mobile devices, so this method can minimize errors in the process absenteeism and payroll.

Keywords: Attendance, Data Monitoring, Payroll, Salary Slip, Licensing

\section{PENDAHULUAN}

PT. Ophthalindo Jaya merupakan salah satu perusahaan yang bergerak di Bidang alat Kesehatan, jumlah karyawan yang dimiliki kurang lebih 30

This work is licensed under a Creative Commons Attribution 4.0 International License. http://journal.stmikjayakarta.ac.id/index.php/JMIJayakarta 
DOI: $10.52362 /$ jmijayakarta.v1i4.551

karyawan Dan sudah memiliki 2 cabang di beberapa kota yaitu Yogyakarta dan Surabaya Perusahaan ini berpusat di DKI Jakarta, Dalam Prosedur Absensi dan penggajian pada PT. Ophtalindo Jaya Sebenarnya sudah mempunyai sistem yang mengatur, namun masih sangat manual untuk cara penerapanya, sehingga dengan cara manual ini perusahaan tidak cukup untuk memonitoring penggajian karyawan jika SDM semakin bertambah dari proses izin sakit, izin cuti, izin keluar pun masih menggunakan penulisan secara manual, Melihat permasalahan yang ada pada PT. Ophthalindo Jaya maka bagian personalia dan keuangan memerlukan sebuah sistem informasi absensi karyawan dan penggajian yang dapat membantu menyelesaian banyaknya permasalahan yang mencul dan mengakibatkan terjadinya kerancuan dan kesalahan data penggajian, Dengan adanya sistem informasi penggajian ini tentunya dapat membantu menyelesaikan permasalahan dan berharap sistem ini dapat berjalan sesuai dengan harapan hal ini dapat mempermudah dalam penyajian informasi yang efektif dan efisien baik bagi pimpinan maupun admin sehingga kedua belah pihak mendapatkan pelayanan yang memuaskan.

\section{DEFINISI}

\subsection{Framework Zachman}

Framework Zachman merupakan alat bantu yang dikembangkan untuk memotret arsitektur organisasi dari berbagai sudut pandang dan aspek, sehingga didapatkan gambaran organisai secara utuh. John A Zachman adalah seorang tokoh yang memperkenalkan pertama kali sebuah kerangka kerja bernama framework Zachman pada tahun 1987 di IBM System Journal, lalu pada tahun 1992 dikembangkan lagi, tujuannya untuk integrasi, pengelolaan, pengembangan, interpretasi, dan mendukung akses dalam menyediakan struktur dasar organisasi.

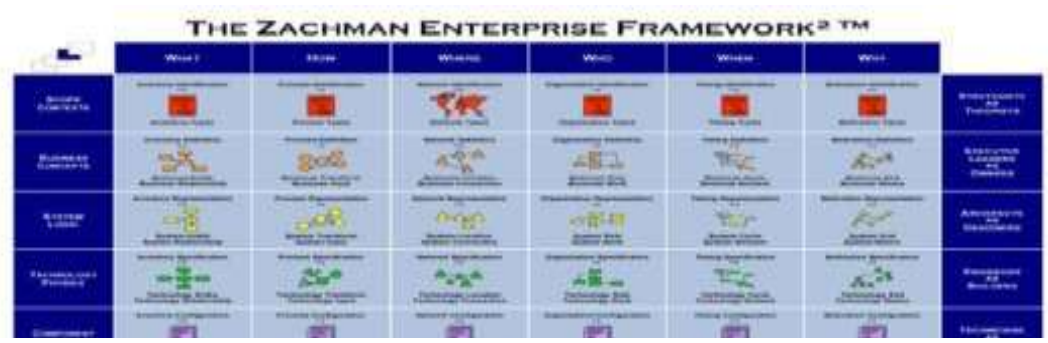

Gambar 1 Contoh Zachman

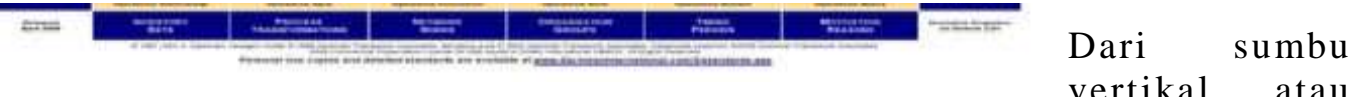

dari baris terdiri dari 6 perspektif, yaitu:

vertikal atau

a. Perspektif Planner (Scope Context) : menjelaskan latar belakang, tujuan, dan data sebuah organisasi.

b. Perspektif Owner (Business Concept) : menetapkan model yang berhubungan dengan bisnis.

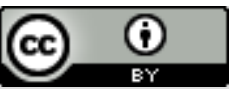

This work is licensed under a Creative Commons Attribution 4.0 International License. http://journal.stmikjayakarta.ac.id/index.php/JMIJayakarta 
DOI: $10.52362 /$ jmijayakarta.v1i4.551

c. Perspektif Designer ( System Logic) : berisi tentang kebutuhan serta desain sekaligus menjembatani hal yang diinginkan pemilik.

d. Perspektif Builder (Technology Physics) : menetapkan model fisik untuk mengoptimalkan desain untuk kebutuhan spesifik.

e. Perspektif Implementer (Component Assemblies) : menjelaskan tentang pengoperasian oleh bagian implementator.

f. Perspektif Participant (Operation Classes) : menjelaskan bahwa participant menggunakan sistem yang telah berfungsi nyata.

Berikut penjelasan pada setiap kolomnya:

1). Kolom What : menjelaskan tentang data yang digunakan

2). Kolom How : menjelaskan tentang proses-proses yang terjadi

3). Kolom Where : menjelaskan tentang lokasi bisnis serta jaringannya

4). Kolom Who : menjelaskan tentang sumber daya manusia yang ikut serta dalam proses bisnis

5). Kolom When : menjelaskan tentang waktu kejadian serta jadwal

6). Kolom Why : menjelaskan tentang motivasi,

\subsection{Definisi Flowmap}

Flowmap merupakan suatu diagram untuk menggambarkan aliran data atau informasi antar bagian-bagian yang terkait dalam sistem. Atau Flow Map dapat juga diartikan sebagai alat bantu yang berbentuk sebuah diagram yang berfungsi untuk memetakan gambaran prosedur-prosedur yang terjadi dalam system"(Muhammad Tesar Sandikapura \& Eko Maulana Sukendar, 2018), Berikut contoh proses simbolnya :

\begin{tabular}{|c|c|}
\hline Simbol & FCeterongen aten \\
\hline & $\begin{array}{l}\text { Pokumen } \\
\text { Manvinulican dokuman berupa dokumen input dan output } \\
\text { pada promes manval dan prosen berbasin komputer }\end{array}$ \\
\hline & 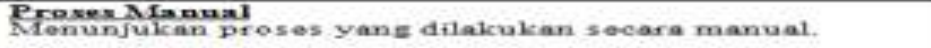 \\
\hline & 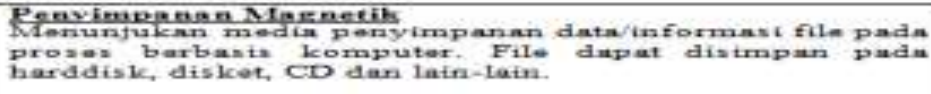 \\
\hline & 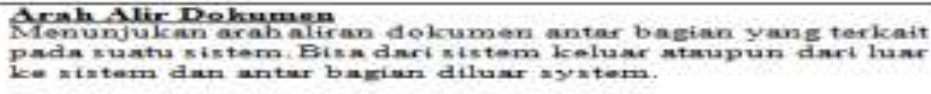 \\
\hline & 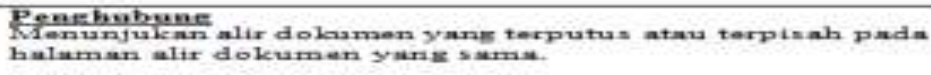 \\
\hline & 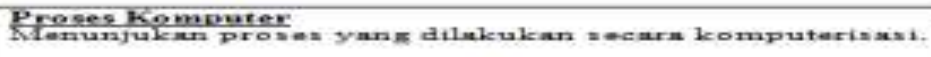 \\
\hline & 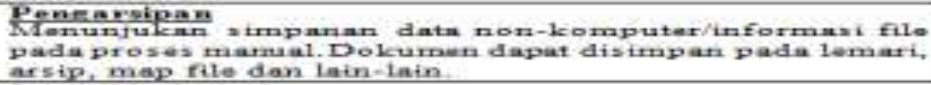 \\
\hline & 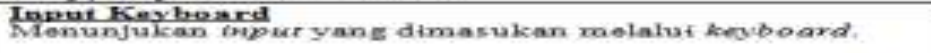 \\
\hline & 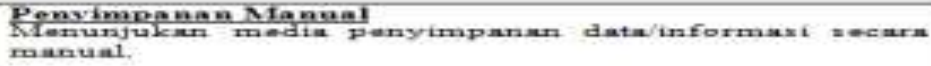 \\
\hline
\end{tabular}

2.3.

efin

isi

ER

D

E

RD

(En tity

This work is licensed under a Creative Commons Attribution 4.0 International License. http://journal.stmikjayakarta.ac.id/index.php/JMIJayakarta 
DOI: $10.52362 /$ jmijayakarta.v1i4.551

Relationship Diagram) merupakan suatu model untuk menjelaskan hubungan antar data dalam basis data berdasarkan objek-objek dasar data yang mempunyai hubungan antar relasi. ERD digunakan untuk memodelkan struktur data dan hubungan antar data, untuk menggambarkannya digunakan beberapa notasi dan simbol, karena hal ini relatif kompleks. Dengan ERD kita dapat menguji model dengan mengabaikan proses yang harus dilakukan. Dewi, Z. R. A. T. D., Ahmadi, C., \& Suardika, I. G. (2015)

\subsection{Definisi UML}

UML merupakan singkatan dari "Unified Modelling Language" yang merupakan bagian suatu metode permodelan secara visual untuk sarana perancangan sistem berorientasi objek. Definisi UML yaitu sebagai suatu bahasa yang sudah menjadi standar pada visualisasi, perancangan dan juga pendokumentasian sistem software. Dengan a UML telah menjadi bahasa standar dalam penulisan blue print software. Salamah, G. U. (2021).

\subsection{Hierarchy Input Process Output (HIPO)}

HIPO adalah alat dokumentasi program yang biasanya dimanfaatkan dalam metode pengembangan suatu perangkat lunak. Sekarng, tool ini juga dimanfaatkan sebagai alat desain dan teknik dokumentasi. Tools menjadi salah satu yang paling tepat untuk menggabarkan siklus pengembangan sistem yang berbasis pada fungsi, yaitu tiap-tiap modul di dalam sistem digambarkan oleh fungsi utamanya. Rahmawati, E., Saifudin, S., Kesuma, C., \& Rais, A. N. (2020).

\subsection{Definisi Absensi}

Absensi kehadiran pegawai merupakan faktor penting bagi sebuah instansi atau perusahaan untuk mencapai tujuan, hal ini berkaitan pada kedisiplinan dan berdampak pada kinerja dari masing-masing pegawai.(Subiantoro \& Sardiarinto, 2018)

\subsection{Definisi Penggajian}

Penggajian merupakan bentuk timbal balik atas suatu ikatan pekerjaan dalam bentuk jasa yang telah dilakukan, yang diberikan oleh perusahaan kepada karyawannya. Dibayarkan dalam bentuk uang yang diatur dan ditetapkan berdasarkan asas perundang-undangan (Rahmawati, M., \& Yaumaidzinnaimah, Y. (2021)).

\section{METODE PENELITIAN}

\subsection{Metode Perancangan sistem}

Zachman Framework menyediakan struktur dasar yang menunjang akses, integrasi,interpretasi serta perubahan representasi arsitektur dari sistem absensi perusahaan. Penelitian ini menggunakan sudut pandang perspektif planner (scope), Owner (business model), designer (system model) dan Builder (technology model) sehingga di peroleh analisis sebagai berikut:

This work is licensed under a Creative Commons Attribution 4.0 International License. http://journal.stmikjayakarta.ac.id/index.php/JMIJayakarta 
DOI: $10.52362 /$ jmijayakarta.v1i4.551

a. Objective / Scope menurut perspektif planner

1). Kolom What

Kolom ini menjelaskan mengenai fakta-fakta yang berpengaruh pada pengembangan sistem dan kendala-kendala yang berkaitan dengan data dan entitas yang ada.

2). Kolom How

Kolom ini menelaskan prosedur dan proses utama yang terjadi pada PT. Ophthalindo Jaya prosedur akan dijelaskan dengan penjelasan detail dari setiap divisi yang ada.

3). Kolom Where

Kolom ini membahas mengenai lokasi perusahaan yang akan menjadi tempat observasi penelitian yaitu dimana PT. Ophthalindo Jaya yang berpusat di Jakarta.

4). Kolom Who

Kolom ini membahas mengenai SDM pada PT. Ophthalindo jaya yang berperan penting dalam proses absensi data karyawan

5). Kolom When

Kolom ini menjelaskan tentang kegiatan yang terjadi pada PT. Ophthalindo Jaya, Yang masih berkaitan dengan sistem absensi yang berjalan.

6). Kolom Why

Kolom ini menjelaskan tentang Visi dan Misi pada PT. Ophthalindo Jaya secara umum.

\section{b. Business Model menurut perspektif Owner}

1). Kolom What

Kolom ini menjelaskan bagaimana tiap entitas yang sudah dijelaskan pada kolom What perpektif Planner saling berhubungan pada proses sistem informasi.

2). Kolom How

Kolom ini berisikan deskripsi dari input,Proses dan Output yang terjadi pada proses absensi pegawai yang sedang berjalan, Deskripsi ini akan digambarkan dengan activity Diagram.

3). Kolom Where

Kolom ini menjelaskan tentang desain jaringan yang ada pada PT. Ophthalindo Jaya

4). Kolom Who

Kolom ini berisikan personil yang akan ditugaskan untuk pembangunan dan pengelolaan sistem absensi

5). Kolom When

Kolom ini dijelaskan Time schedule dalam pembangunan keseluruhan proyek sistem sebagai acuan dalam membangun sistem absensi pegawai.

6). Kolom Why

Kolom ini mengidentifikasikan tujuan yang ingin di capai oleh PT. Ophthalindo Jaya dari sistem absensi pegawai yang akan dibangun.

This work is licensed under a Creative Commons Attribution 4.0 International License. http://journal.stmikjayakarta.ac.id/index.php/JMIJayakarta 
DOI: $10.52362 /$ jmijayakarta.v1i4.551

\section{c. System Logic / Sistem Model menurut perspektif Designer}

1). Kolom What

Kolom ini dijelaskan mengenai relasi table dan entitas yang ada pada sistem absensi PT, Ophthalindo Jaya, dimana relasi tersebut digambarkan dalam bentuk ERD.

2). Kolom How

Kolom ini merupakan kelanjutan penjelasan dari kolom What, Dimana pada kolom What perspektif Owner, use case dijabarkan secraa menyeluruh semua divisi, namun pada use case ini dibuat secara detail pada setiap divisi.

3). Kolom Where

Kolom ini menjelaskan tentang desain jaringan yang akan di usulkan untuk sistem absensi pegawai pada PT. Ophthalindo Jaya.

4). Kolom Who

Kolom ini berisikan rancangan manual interface, sistem absensi pada PT. Ophthalindo Jaya yang terdiri dari desain input, proses, output, dan interface. Desain table.

5). Kolom When

Kolom ini dijelaskan secara detail jadwal perancangan model yang digambarkan dalam bentuk Time Schedule.

6). Kolom Why

Kolom ini menjabarkan aturan-aturan dalam pembuatan model sistem absensi penggajian pada PT.Ophthalindo Jaya.

\section{d. Technology Model Menurut perspektif Builder}

1). Kolom What

Kolom ini dijelaskan relasi antar table yang terdapat dalam sistem absensi penggajian pada PT. Ophthalindo Jaya.

2). Kolom How

Kolom ini menjelaskan jalanya sistem pada masing-masing divisi ,yang digambarkan dengan Sequence Diagram .

3). Kolom Where

Kolom ini menjelaskan tentang lokasi penempatan sistem absensi pada PT. Ophthalindo Jaya.

4). Kolom Who

Kolom ini berisikan gambar interface aplikasi yang sedang berjalan yang akan dikembangkan dengan sistem yang akan di usulkan nantinya

5). Kolom When

Kolom ini dijelaskan detail jadwal perancangan sistem absensi penggajain pada PT. Ophthalindo Jaya

6). Kolom Why

Kolom ini menjabarkan aturan-aturan dalam pembuatan sistem absensi dan penggajian pada PT. Ophthalindo Jaya.

This work is licensed under a Creative Commons Attribution 4.0 International License. http://journal.stmikjayakarta.ac.id/index.php/JMIJayakarta 
DOI: $10.52362 /$ jmijayakarta.v1i4.551

\section{IMPLEMENTASI}

4.1. List Of Function (Daftar fungsi / Modul)

Berikut ini adalah daftar fungsi / modul yang dibutuhkan untuk melakukan pengolahan data absensi pada sistem web

Tabel 1 Fungsi Modul Sistem

\begin{tabular}{|l|l|l|l|}
\cline { 2 - 4 } \multicolumn{1}{c|}{} & No & Nama Fungsi/Module & Keterangan \\
\hline 1 & Modul Admin & Input, Edit, Delete data user \\
\cline { 2 - 4 } & 2 & Modul User & Input,Download \\
\cline { 2 - 4 } & 4.2. B \\
$\mathbf{~}$ & 3 & Modul Perizinan & Input,Edit,Delete \\
\cline { 2 - 4 } & 4 & Modul Laporan & Export Laporan data kehadiran \\
\cline { 2 - 4 } & &
\end{tabular}

ness Flow (Diagram Proses Bisnis)

a. Flowmap Sistem

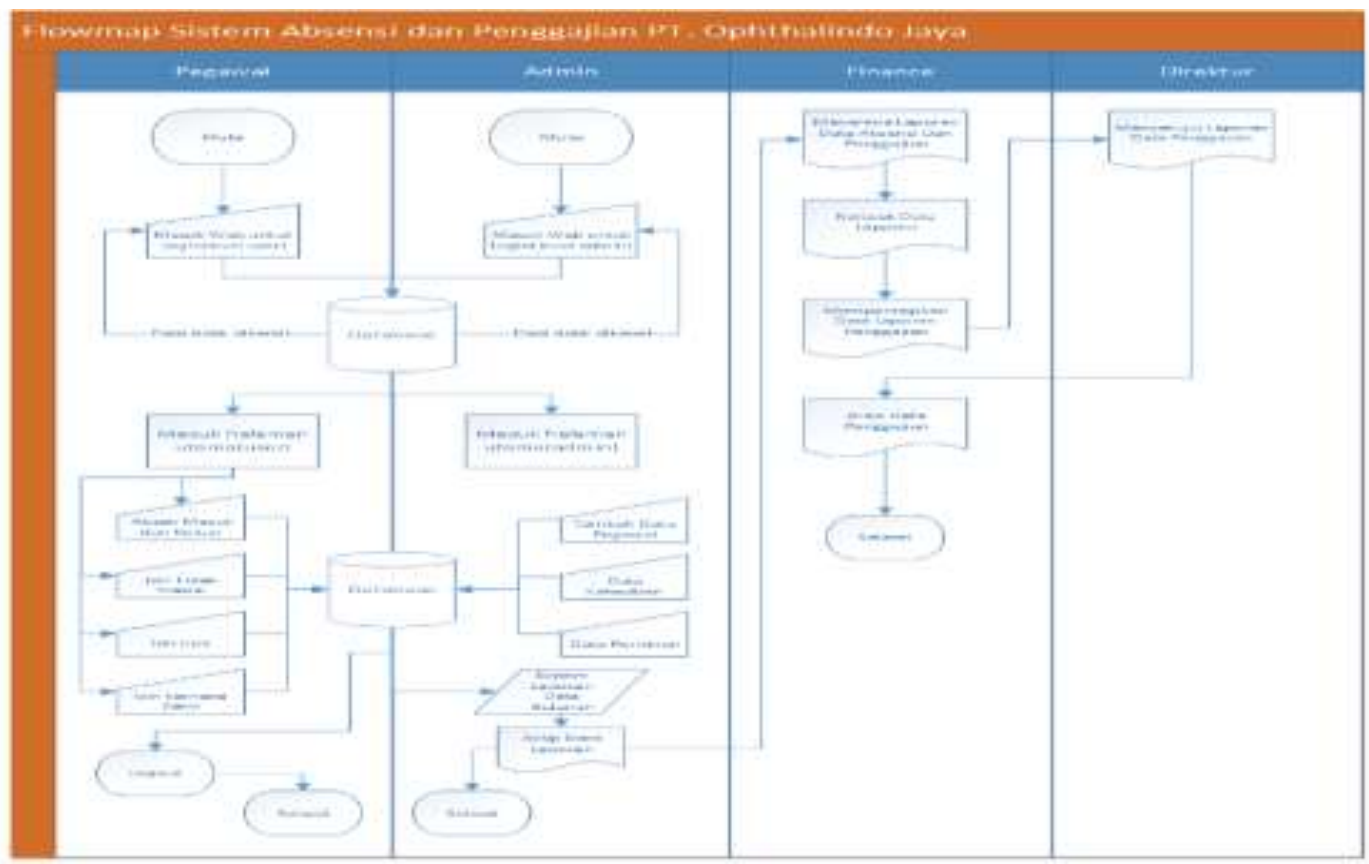

(c) (i)

This work is licensed under a Creative Commons Attribution 4.0 International License. http://journal.stmikjayakarta.ac.id/index.php/JMIJayakarta 
DOI: $10.52362 / j m i j a y a k a r t a . v 1 i 4.551$

\section{b. UML (Unified Modeling Languange)}

Aplikasi yang berjalan dianalisa dengan menggunakan UML (Unified Modeling Language).

1) Use Case Diagram

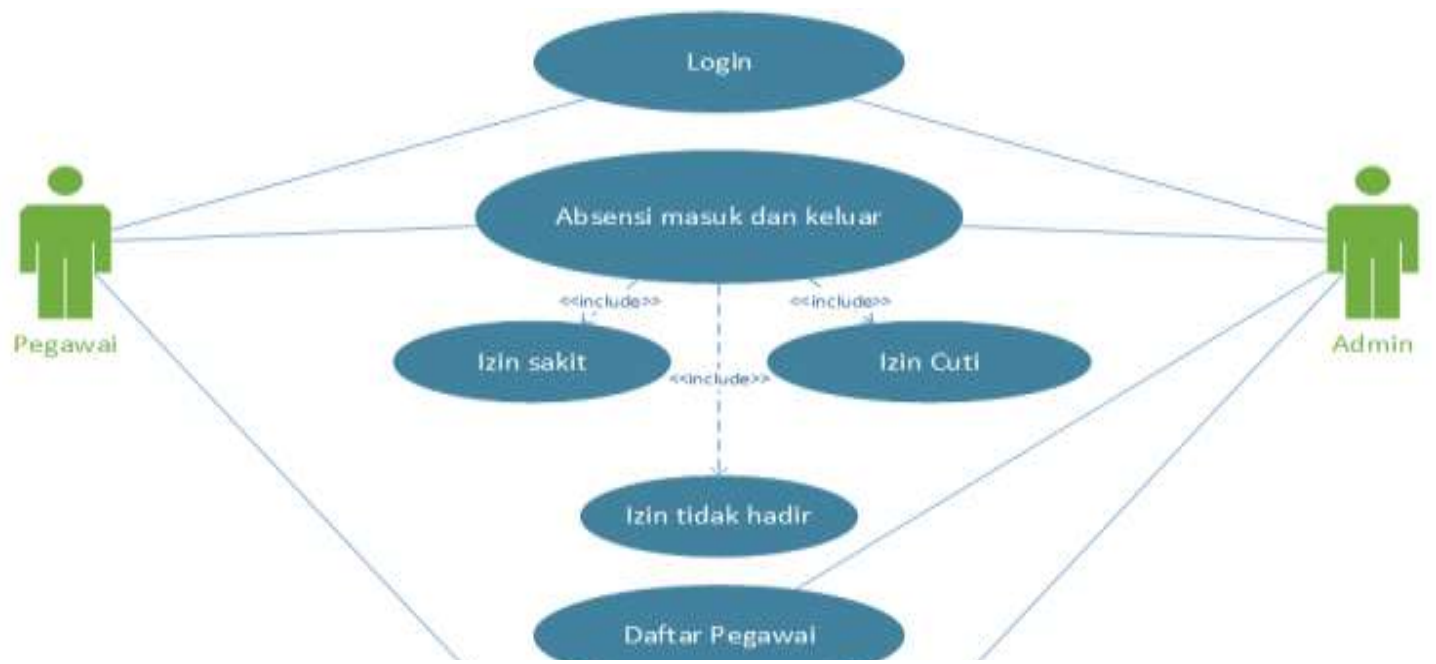

Gambar 3 Flowmap Sistem Absensi Dan Penggajian

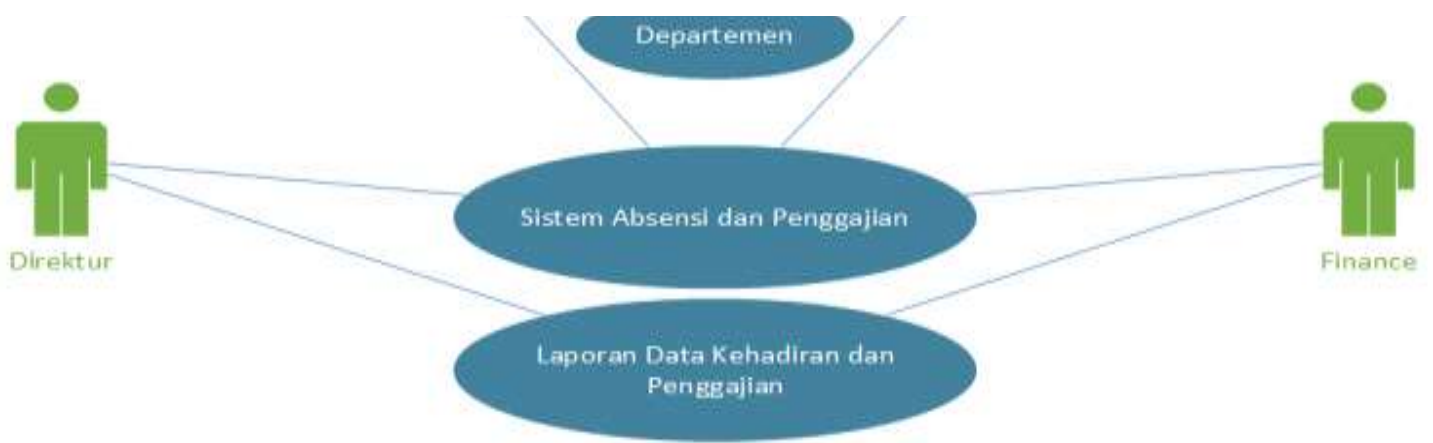

Gambar 4 Use Case Diagram Sistem Absensi Dan Penggajian

Use Case Diagram pada bagian Absensi dan penggajian pada PT. Ophthalindo Jaya dapat dilihat pada gambar 4. sebagai berikut :

a. 1(satu) Sistem yang mencakup kegiatan proses kehadiran

b . 4(empat) actor yang melakukan kegiatan yaitu Pegawai, Admin, Finance, Direktur

c. 4(empat) use case yang terdiri dari absen masuk dan keluar, daftar pegawai baru, sistem absensi dan penggajian, laporan data kehadiran dan penggajian.

\section{2) Class Diagram}

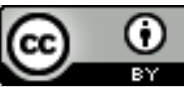

This work is licensed under a Creative Commons Attribution 4.0 International License. http://journal.stmikjayakarta.ac.id/index.php/JMIJayakarta 
DOI: $10.52362 /$ jmijayakarta.v1i4.551

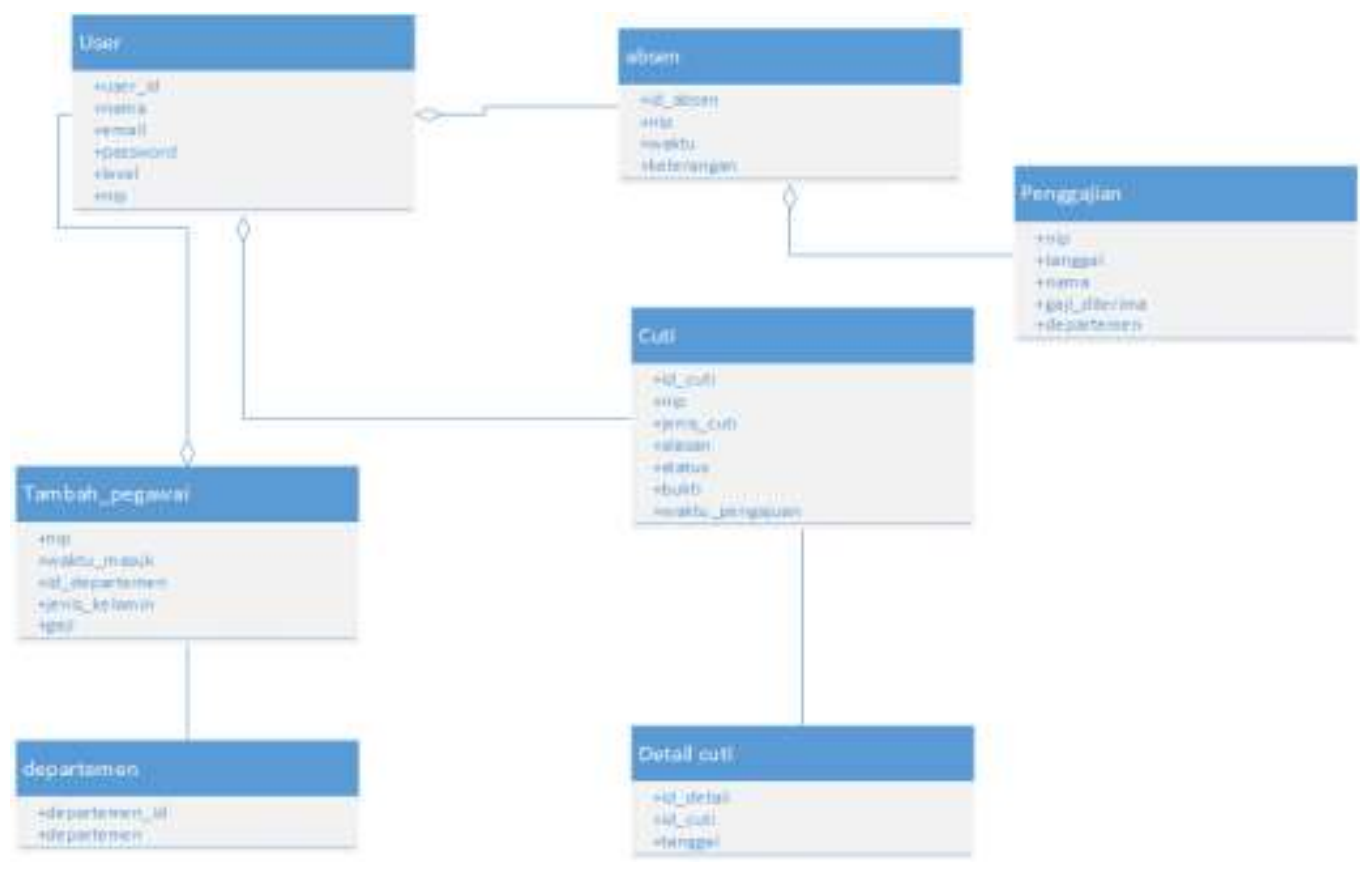

Gambar 5 Class Diagram Pada Sistem Absensi Dan Penggajian

\subsection{Teknik Spesifikasi Dokumen}

1) Topologi jaringan yang digunakan Topologi star

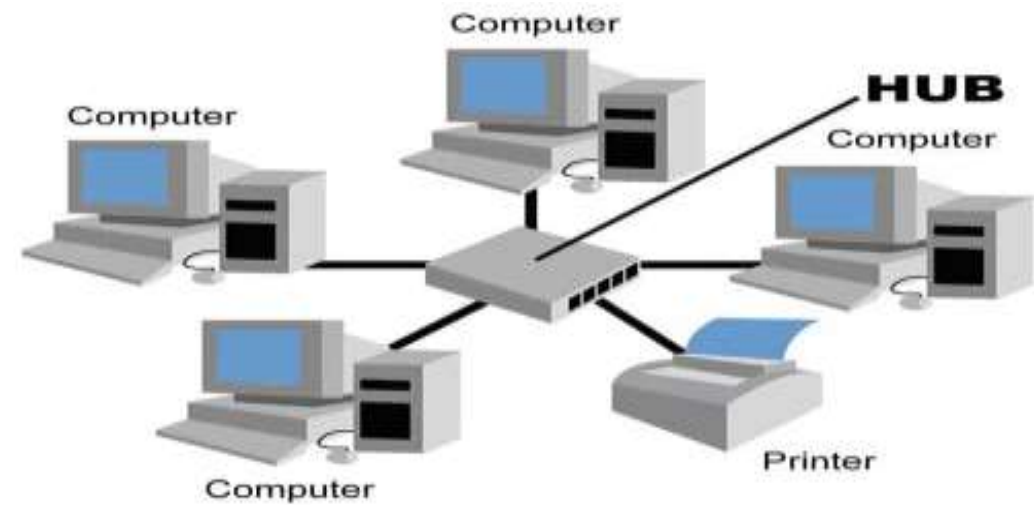

Gambar 6 Topology Jaringan

\section{(c) (7)}

This work is licensed under a Creative Commons Attribution 4.0 International License. http://journal.stmikjayakarta.ac.id/index.php/JMIJayakarta 
DOI: $10.52362 /$ jmijayakarta.v1i4.551

\subsection{Spesifikasi Software}

menjelaskan bahwa beberapa software yang digunakan dalam pembuatan Web Absensi dan penggajian pegawai.

Tabel 2 Software yang di butuhkan untuk sistem usulan yang akan di jalankan

\begin{tabular}{|l|l|l|l|}
\hline No & \multicolumn{1}{|c|}{ Nama Softwar } & Jenis Software & \multicolumn{1}{|c|}{ Keterangan } \\
\hline 1 & Windows 10 Pro & Platform & Sistem Operasi Windows \\
\hline 2 & Visual Code & Text Editor & $\begin{array}{l}\text { Untuk proses editor } \\
\text { pengembangan }\end{array}$ \\
\hline 3 & Mysql & Database & $\begin{array}{l}\text { Database yang digunakan pada } \\
\text { WEB Absensi }\end{array}$ \\
\hline 4 & Ms Office & Report & $\begin{array}{l}\text { Untuk Menyimpan suatu } \\
\text { laporan yang telah di export }\end{array}$ \\
\hline
\end{tabular}

\subsection{Spesifikasi Hardware}

Untuk menggunakan aplikasi Web Absensi, Maka diperlukan perangkat keras(Hardware) sebagai berikut :

Tabel 3 Spesifikasi Hardware Yang Dibutuhkan

\begin{tabular}{|c|l|}
\hline No & Keterangan Hardware \\
\hline 1 & Intel Core i3 \\
\hline 2 & Ram 4Gb DDR4 \\
\hline 3 & Hard disk 1Tb \\
\hline
\end{tabular}

\subsection{ERD(Entity Relationship Diagram)}

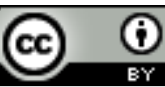

This work is licensed under a Creative Commons Attribution 4.0 International License. http://journal.stmikjayakarta.ac.id/index.php/JMIJayakarta 
DOI: $10.52362 /$ jmijayakarta.v1i4.551

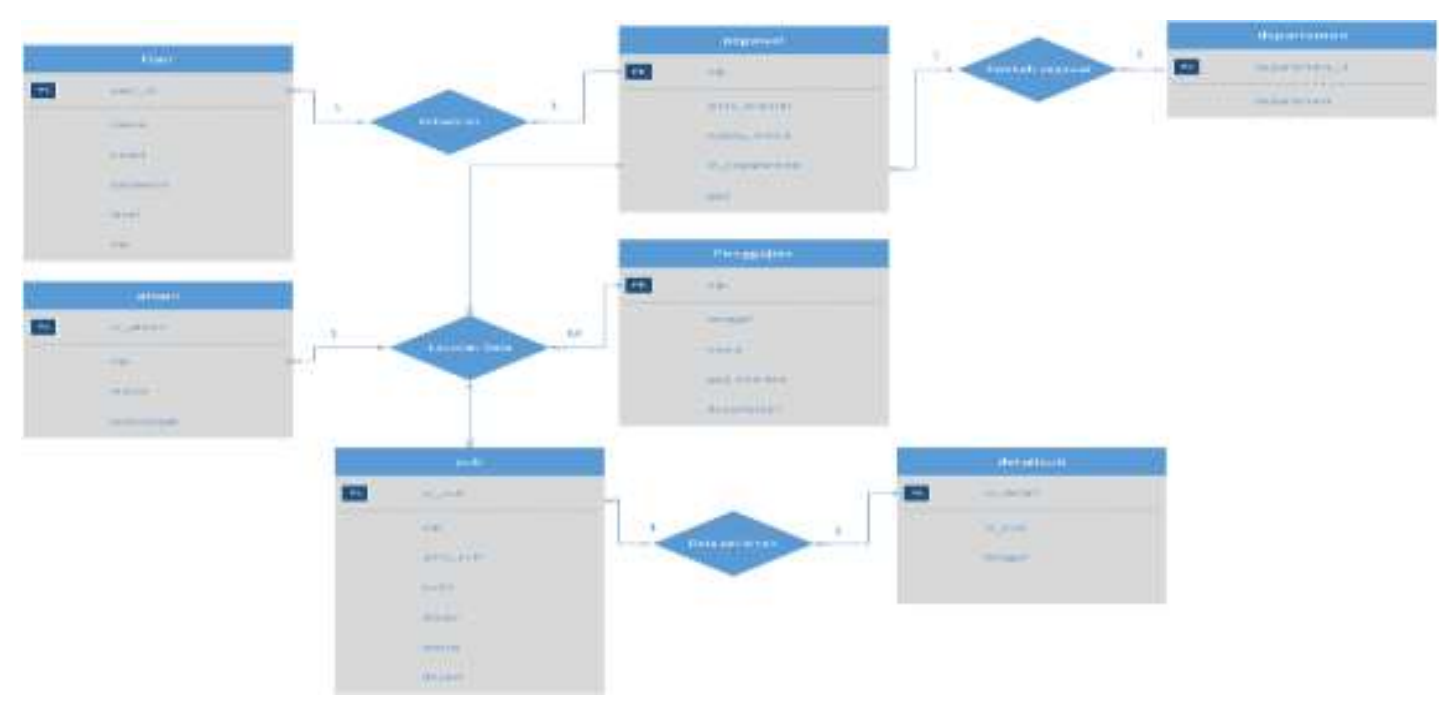

Gambar 7 ERD Sistem Absensi Dan Penggajian

\subsection{Hierarcy Input Proses Output (HIPO)}

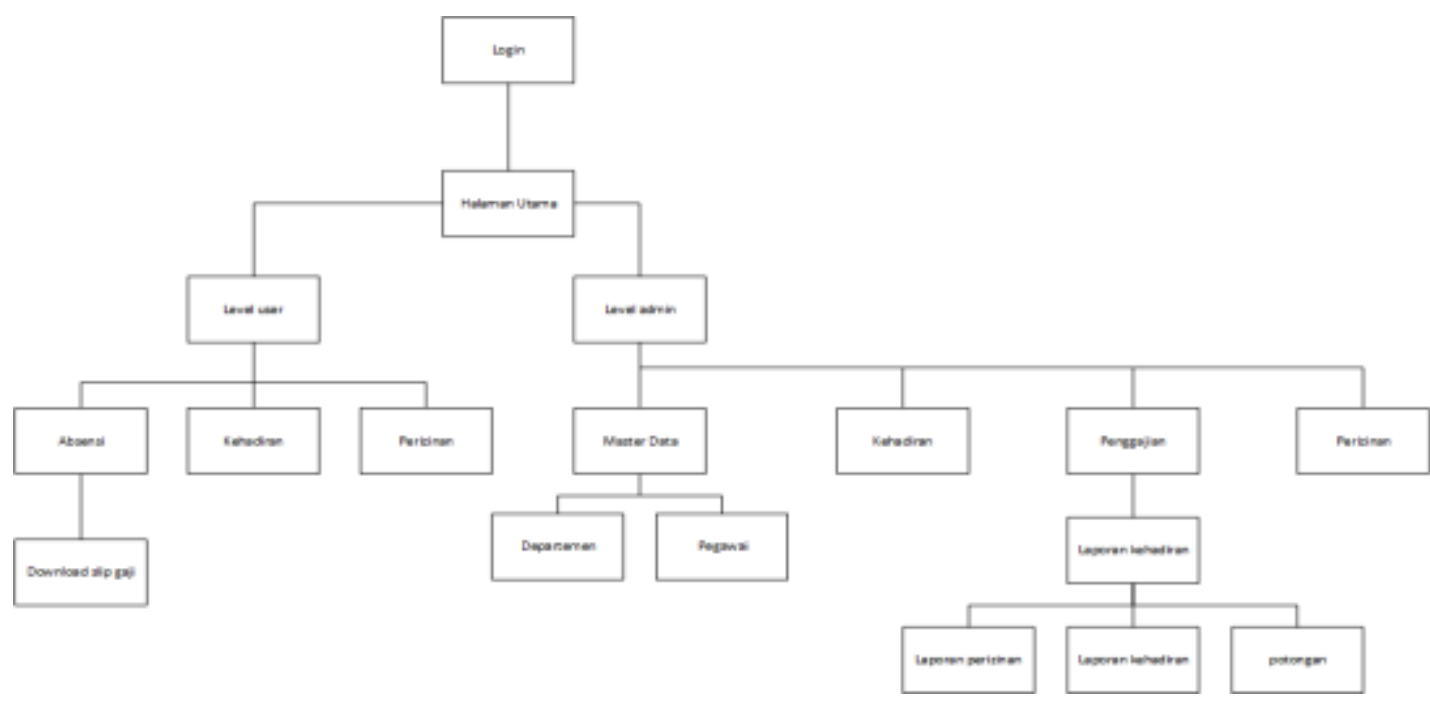

Gambar 8 Kerangka Sistem HIPO

\section{(c) (i)}

This work is licensed under a Creative Commons Attribution 4.0 International License. http://journal.stmikjayakarta.ac.id/index.php/JMIJayakarta 
DOI: $10.52362 /$ jmijayakarta.v1i4.551

\subsection{Tampilan Database}

Berikut adalah beberapa data untuk memenuhi proses aplikasi web absensi dan penggajian pegawai

a. Database Absensi dan Penggajian

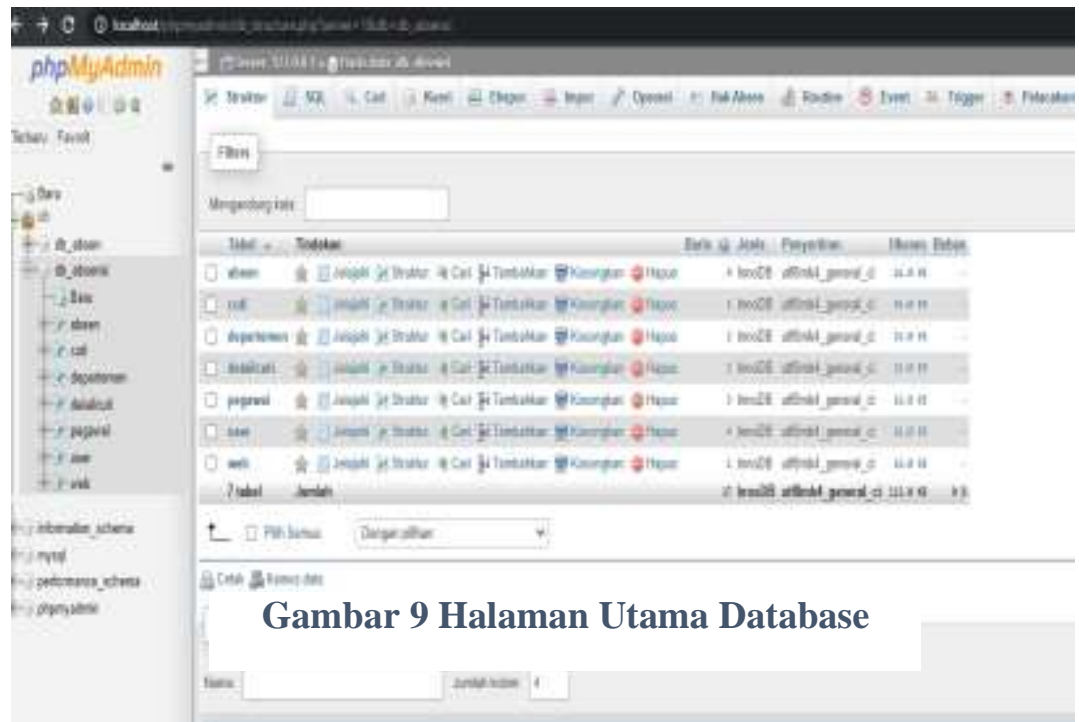

Absensi

b. Data

Akses

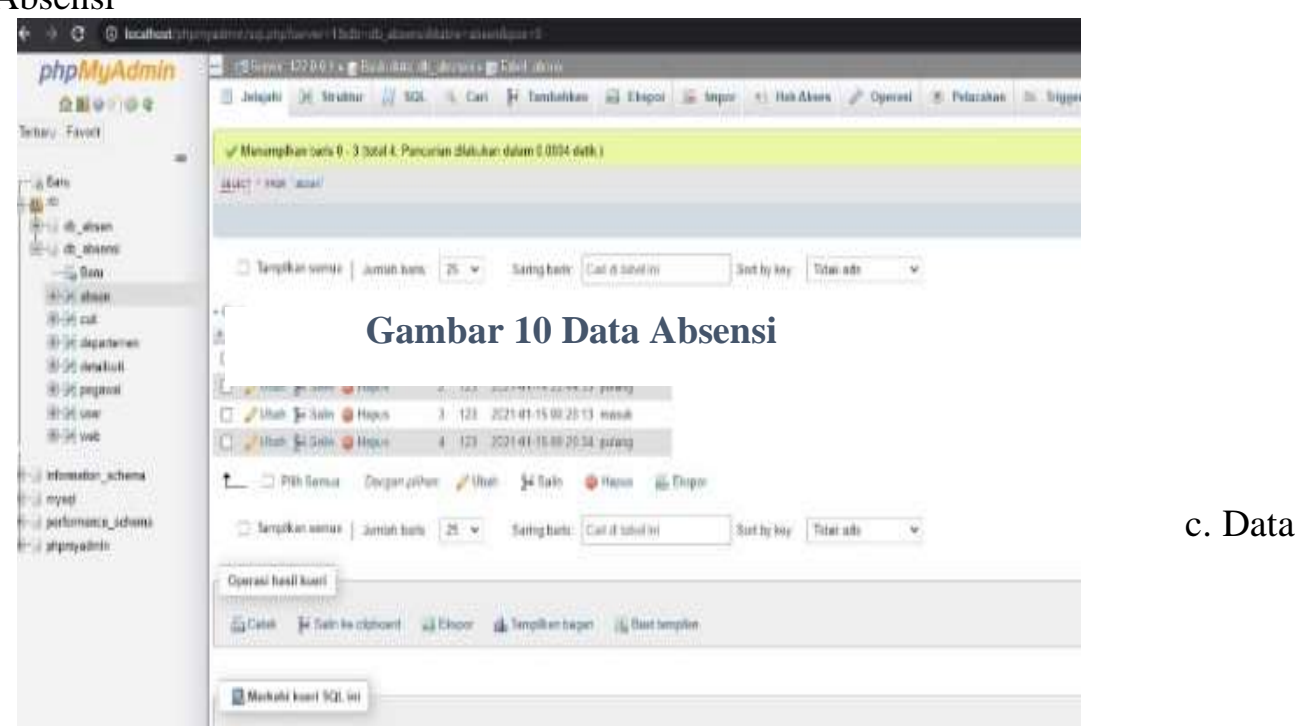

Departemen

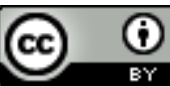

This work is licensed under a Creative Commons Attribution 4.0 International License. http://journal.stmikjayakarta.ac.id/index.php/JMIJayakarta 
DOI: 10.52362/jmijayakarta.v1i4.551

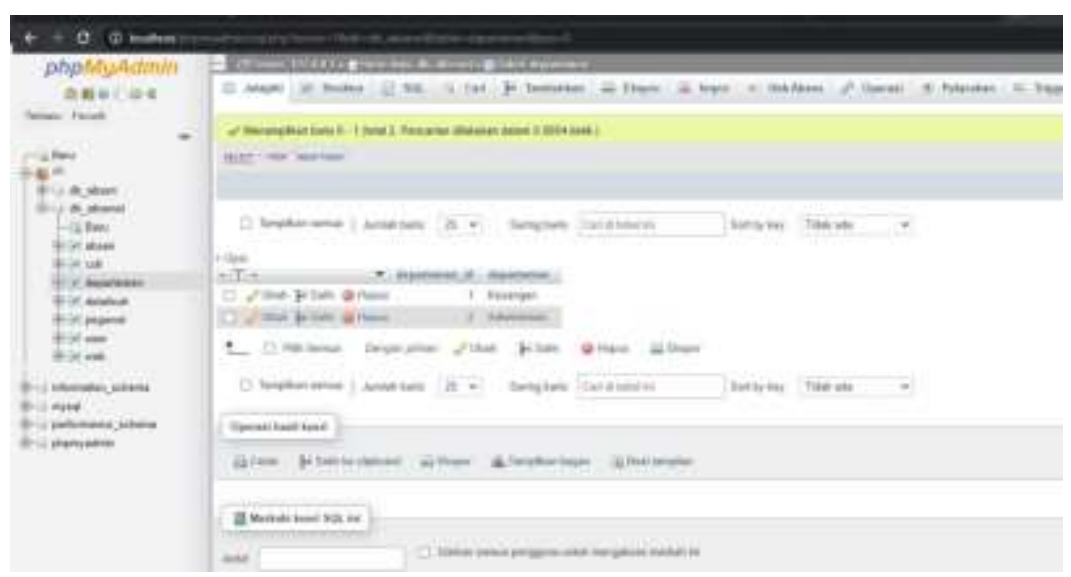

d. Data User

Gambar 11 Data Departemen

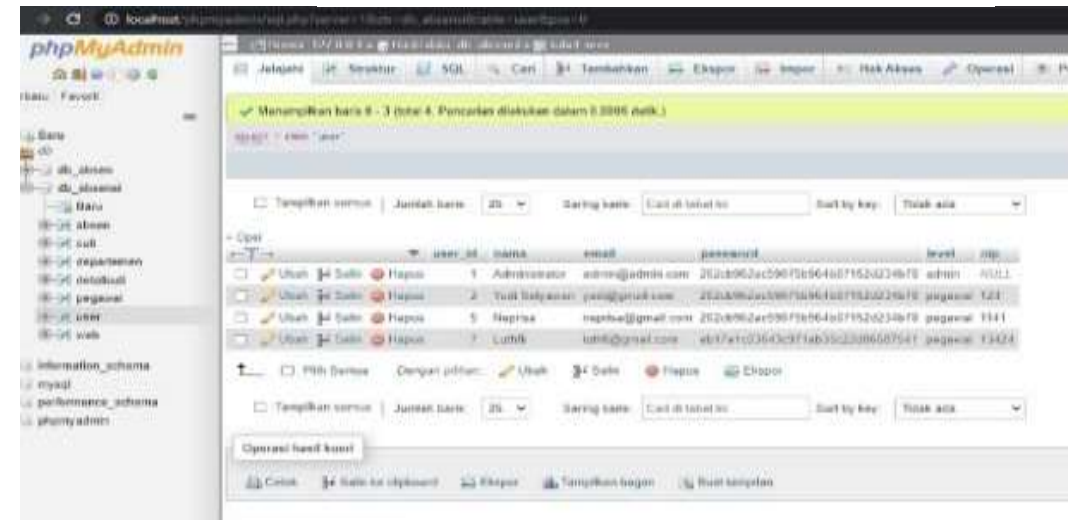

Gambar 12 Data User

e. Data

Pegawai

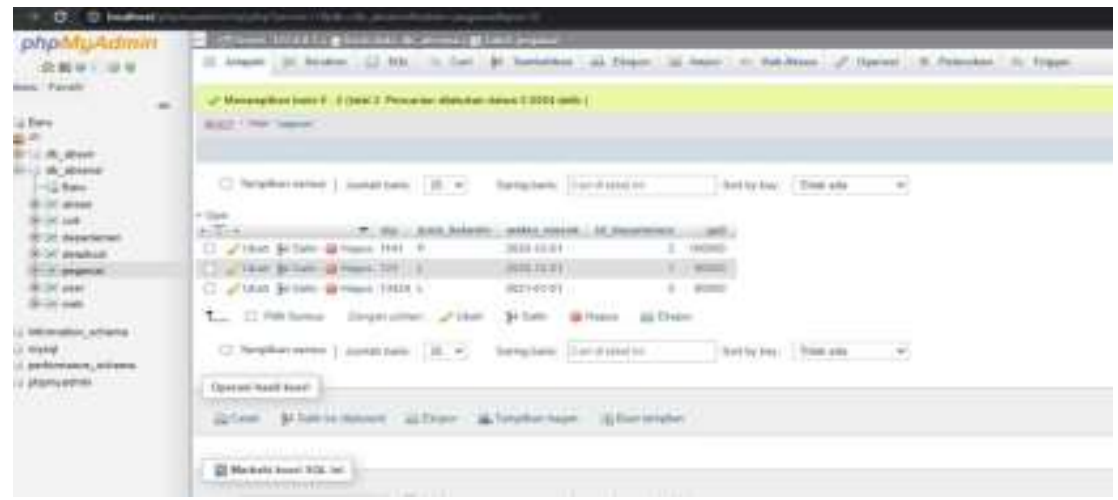

Gambar 13 Data Pegawai

\subsection{Tampilan Aplikasi}

\section{a. Tampilan Login}

\section{cc) (i)}

This work is licensed under a Creative Commons Attribution 4.0 International License. http://journal.stmikjayakarta.ac.id/index.php/JMIJayakarta 
DOI: $10.52362 /$ jmijayakarta.v1i4.551

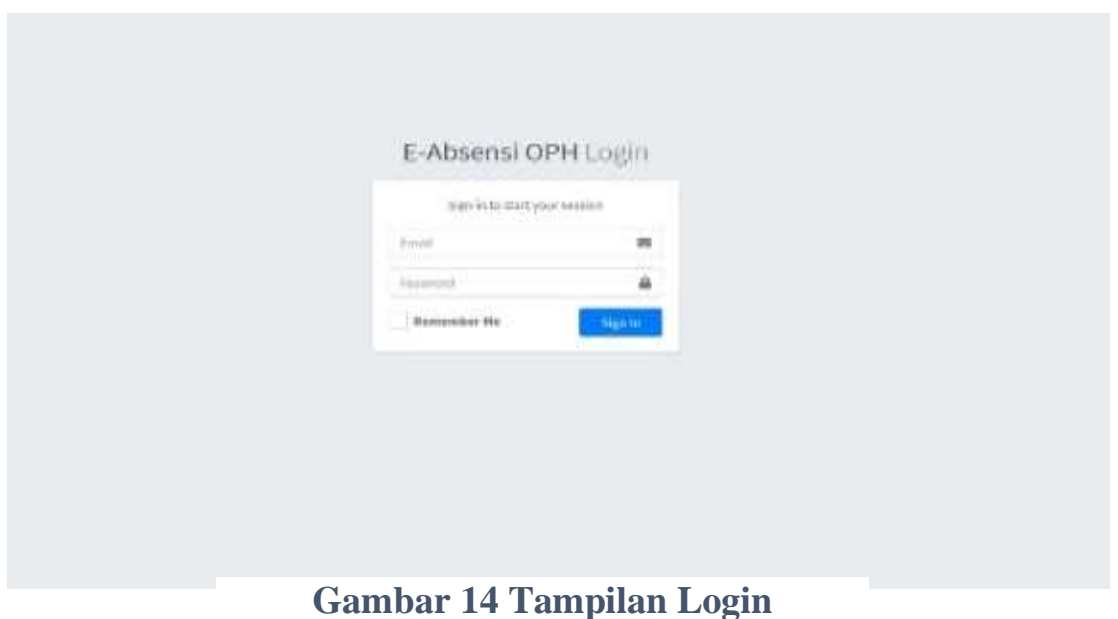

b. Tampilan Menu Utama Admin

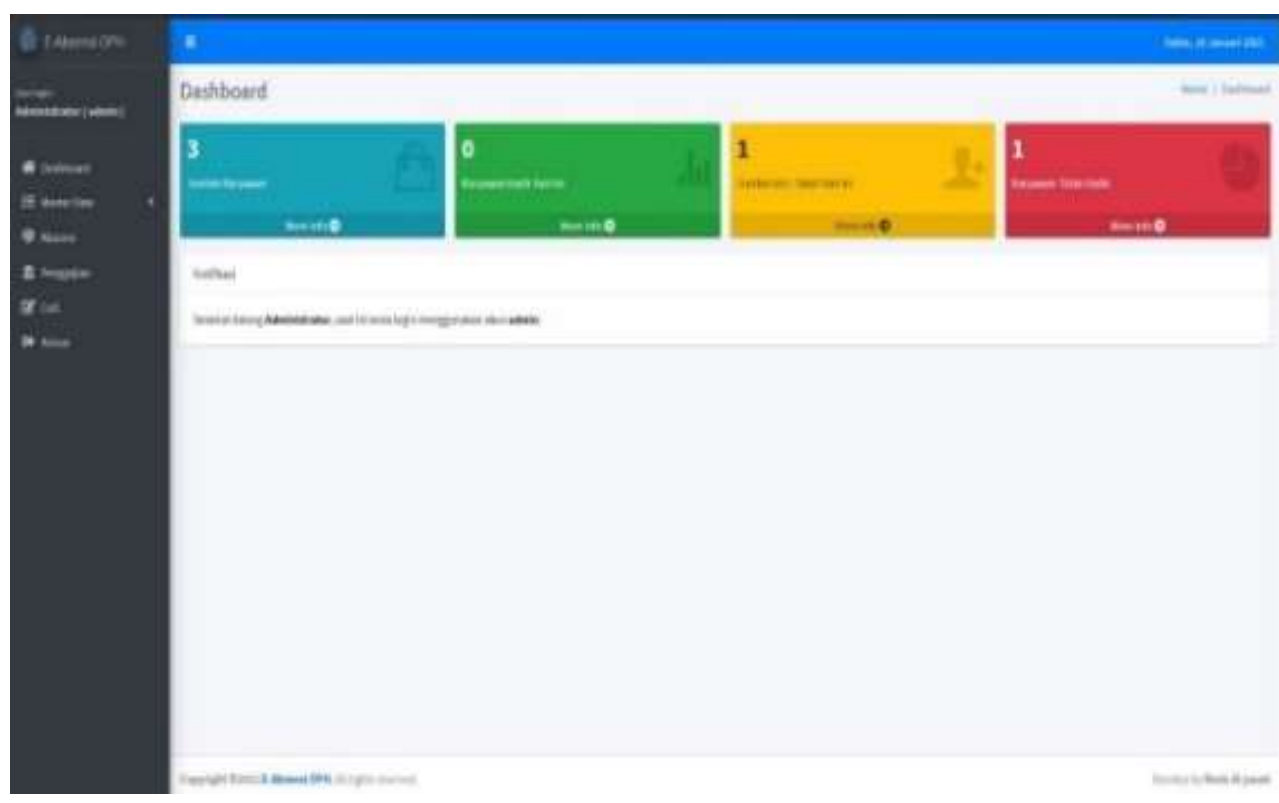

Gambar 15 Tampilan Menu Utama

\section{c. Tampilan Absensi}

\section{(c) (i)}

This work is licensed under a Creative Commons Attribution 4.0 International License. http://journal.stmikjayakarta.ac.id/index.php/JMIJayakarta 
DOI: $10.52362 /$ jmijayakarta.v1i4.551

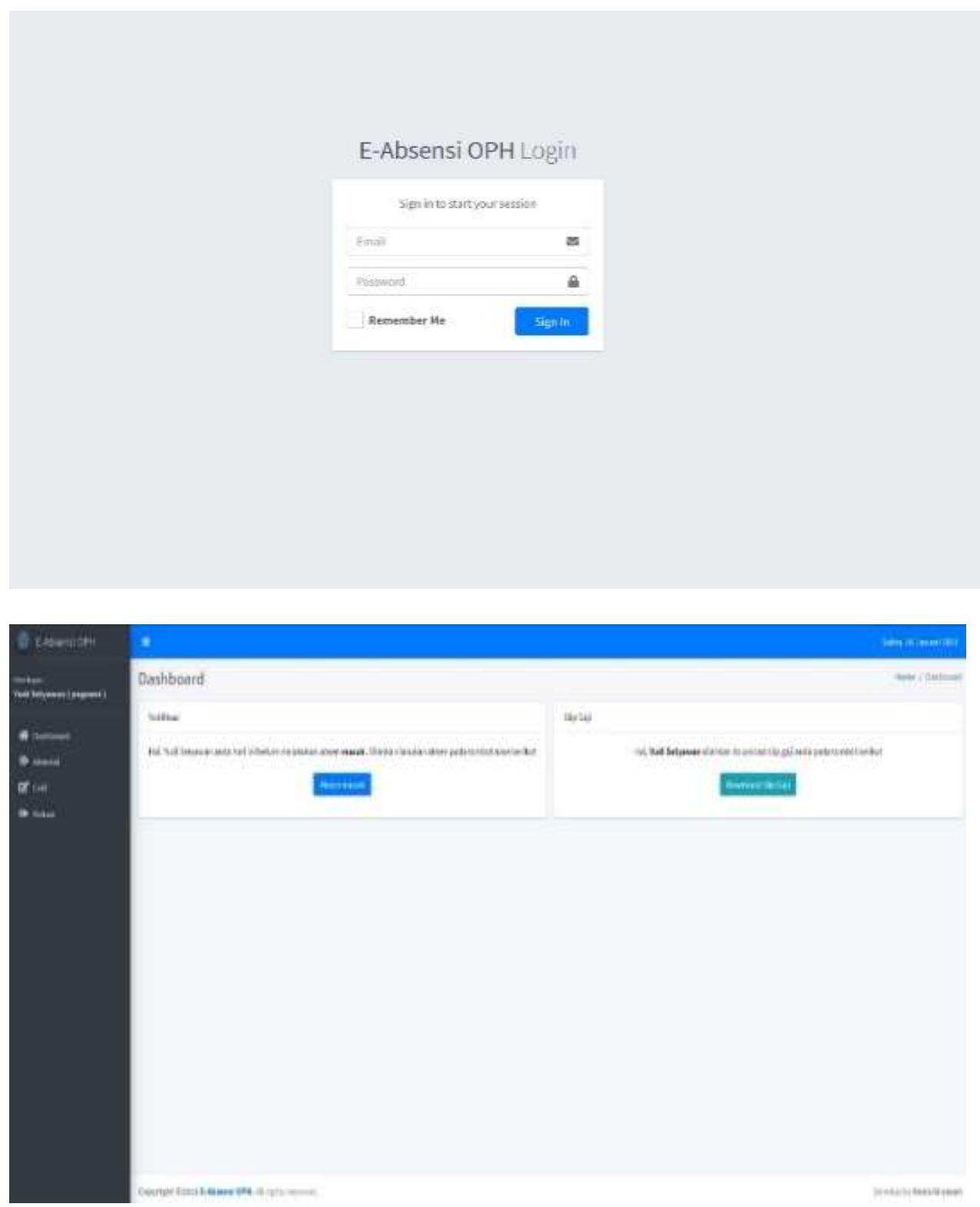

Gambar 16 Menu Absensi

(c) (7)

This work is licensed under a Creative Commons Attribution 4.0 International License. http://journal.stmikjayakarta.ac.id/index.php/JMIJayakarta 
DOI: $10.52362 /$ jmijayakarta.v1i4.551

\section{KESIMPULAN}

a. Membangun sistem keamanan yang terjaga dengan cara masuk Login dan masuk ke halaman utama yang nantinya halaman tersebut memudahkan kita untuk mengakses semua sesuai kebutuhanya.

b. Membangun sistem absensi dan penggajian yang dilengkapi dengan pembatasan atau pengendalian hak akses ke dalam sistem yaitu melalui user id dan password.

c. Membangun sistem perizinan yang bersifat terdata dengan rapih, Sehingga sangat memudahkan user untuk melakukan perizinan dan memudahkan admin untuk memonitoring suatu aktivitas semua karyawan yang ada pada perusahaan tersebut.

d. Membangun sistem penggajian karyawan secara otomatis slip gaji akan terhitung dengan gaji yang didapatkan setiap karyawan.

\section{REFERENCE}

[1]. Audrilia, M., \& Budiman, A. (2020). Perancangan Sistem Informasi Manajemen Bengkel Berbasis Web (Studi Kasus : Bengkel Anugrah). Jurnal Madani : Ilmu Pengetahuan, Teknologi, Dan Humaniora, 3(1), 1-12. https://doi.org/10.33753/madani.v3i1.78

[2]. Aprianti W, Maliha U. (2016). Sistem Informasi Kepadatan Penduduk Kelurahan Atau Desa Studi Kasus Pada Kecamatan Bati-Bati. Jurnal Sains dan Informatika Volume 2, Nomor 1, Juni 2016.

[3]. Asmara R, Alhamidi. (2017) Pengolahan data rehabilitasi penyalahgunaan narkoba pada klinik aqilah Payakumbuh. Jurnal Sistem Informasi Dan Manajemen Informatika.

[4]. Astriyani E, Putri F, Widianingsih N. (2020). Desain Sistem Informasi Monitoring Aset. Jurnal Teknologi. (2020),87-99 6(1).

[5]. Dewi, Z. R. A. T. D., Ahmadi, C., \& Suardika, I. G. (2015). Dashboard Executive Information System pada Banjar Berbasis Web. Eksplora Informatika, 1, 1-9. Retrieved from http://ejournal.stikombali.ac.id/index.php/josinfo/article/view/300

[6]. Hamizan A, Mayasari M, Saputri R et al. (2020). Sistem Informasi Penggajian di PT. Perkebunan Nusantara IV. Jurnal Manajemen Informatika (JAMIKA), (2020) 29-38,10(1).

[7]. Haitami M, Mutia 1, Septiani N. (2020). Sistem Informasi Pengelolaan Rekam Medis Rumah Sakit Menggunakan Java. STRING (Satuan Tulisan Riset dan Inovasi Teknologi). (2020), 87,5(1).

[8].Pujiwidodo d. (2016). Sistem informasi pengolahan data penanggulangan bencana pada kantor badan penanggulangan bencana daerah (bpbd) kabupaten padang pariaman. Jurnal J-Click Vol 3 No 2 Desember 2016.

[9]. Rahmawati,M.,\&Yaumaidzinnaimah, Y. (2021). Sistem Informasi Penggajian Karyawan Berbasis Java Desktop. INOVTEK Polbeng Seri Informatika, 6(1), 51. https://doi.org/10.35314/isi.v6i1.1856

This work is licensed under a Creative Commons Attribution 4.0 International License. http://journal.stmikjayakarta.ac.id/index.php/JMIJayakarta 
DOI: $10.52362 /$ jmijayakarta.v1i4.551

[10]. Rahmawati, E., Saifudin, S., Kesuma, C., \& Rais, A. N. (2020). Rancang Bangun Sistem Informasi Rekam Medik Studi Kasus: UPTD Puskesmas Padamara Kabupaten Purbalingga. Indonesian Journal on Software Engineering (IJSE), 6(1), 133-144. https://doi.org/10.31294/ijse.v6i1.7860

[11]. Rahmatya M, Faris M. (2016). Pengembangan Sistem Informasi Akademik Berbasis Web Pada SMA Pasundan 2 Bandung. Jurnal Manajemen Informatika (JAMIKA) (2016) Vol.6 No.1

[12]. Subiantoro, \& Sardiarinto. (2018). Perancangan Sistem Absensi Pegawai Berbasis Web. Jurnal Swabumi, 6(2), 184-189.

[13]. Salamun, Sukri,Luluk Elvitaria et al. (2020). Quick Response Code untuk Monitoring Kehadiran Kuliah Dosen. SATIN - Sains dan Teknologi Informasi, (2020), 53-61, 6(1).

[14]. Widodo P, Wijayanti K. (2020). Perancangan Sistem Informasi Penjualan Besi Berbasis Web Pada Cv. Mulya Jaya Yogyakarta. Bianglala Informatika,(2020). 49-57, 8(1).

[15]. Yudowicitro, R. C., Hermawan, \& Yunitarini, R. (2014). Rancang Bangun Erp Pada Modul Inventory Management Menggunakan Zachman Framework. Jurnal SimanteC, 4(2), 125-133. 